\title{
THE STUDY OF REALITIES AND PROSPECTS OF INTERACTION OF UKRAINE WITH EUROPEAN FINANCIAL ORGANIZATIONS IN THE CONDITIONS OF INTEGRATION PROCESSES
}

\author{
Volodimyr Onischenko \\ Poltava National Technical University of Yurij Kondratyuk \\ 24 Pershotravnevy ave., Poltava, Ukraine, 36011 \\ Tatyana Romanova \\ Department of Economic of Enterprises and Staff Management \\ Poltava National Technical University of Yurij Kondratyuk \\ 24 Pershotravnevy ave., Poltava, Ukraine, 36011 \\ tands_r@mail.ru
}

\begin{abstract}
In the article were analyzed the prospects of cooperation between Ukraine and EU structural funds. There was studied the current state of interaction between Ukraine and EIB and EBRD, offered the directions of its optimization. It was proved, that the base of increase of effectiveness of the use of investment resources of European financial organizations by Ukraine and approach of prospects of widening of the credit projects spectrum is not only the clear regulation of the national strategy of economic development but also the improvement of the system of monitoring of the use of investment resources.

Keywords: European integration, economic policy of Ukraine, EU structural funds, European investment bank, European bank for reconstruction and development.

\section{Introduction}

An activity of European financial organizations is the one of most important elements of global economic environment and the one of main factors of guaranteeing stability of its functioning and development. European financial organizations due to accumulation of the significant volumes of financial resources act as one of the main strategic investors for the national economies. Intensification of activity of European integration vector for Ukraine conditions the possibility of widening of cooperation with EU structural funds and also EBRD and EIB. Diversification of the spectrum of mastering the credit sources of such a level conditions not only the possibility of realization of the most complicated tasks in the strategy of development of the national economy and transformation of its structure but also allows use the expert economic information that is a part of the common projects of European financial organizations and Ukraine.
\end{abstract}

\section{Analysis of the literary sources}

The problem of formation of economic policy in the context of European integration and also the study of the role of international help in reformation of the native economy are considered in scientific work of many native and foreign scientists. Thus, the scientific works of foreign scientists were devoted to the study of principles of European policy [1-3]. The assessment of the policy of European integration, analysis of policy of European development, especially the absence of vertical mobility of auxiliary regions and regional convergence were realized in [4]. The study of the role of European structural funds in the development of national economies was carried out in scientific researches [5-7]. The use of EU structural funds in the development of stable energetic in the new EU member states is considered in the article [8]. The assessment of programs of EU structural funds was carried out by the Center of strategy and assessment services in 2004-2006 [9]. The activity of European investment bank and European bank for reconstruction and development, their role in the development of economy and separate business structures was studied in [10-15].

The features of structural transformations in Ukrainian economy, their influence on economical development of Ukraine in the context of European integration processes, prognostication 
of structural shifts in Ukrainian economy as a result of signing agreement between Ukraine and EU are deeply studied in scientific report [16]. The experience of Poland, gained in the process of creation of the legal base of integration with EU and possibilities of its use for Ukraine is analyzed in [17].

\section{Aim and tasks of research}

The aim of the article is the study of prospects of cooperation between Ukraine and EU structural funds and analysis of the features of the current interaction between Ukraine and EIB and EBRD.

For attaining this aim the following tasks were set:

1. To analyze the system of EU structural funds and directions of their interaction with the national economic systems. To elucidate the objective directionality of the activity of EU structural funds.

2. To elucidate the stages of cooperation between Ukraine and European investment bank (EIB). To conduct classification of EIB projects in Ukraine by directions of the use of investment costs.

3. To study the directions of cooperation between Ukraine and European bank for reconstruction and development (EBRD) and separate their features.

\section{The necessity of involvement of external sources of financing for the development of Ukrainian economy}

The influence of world financial system on the functioning of Ukrainian economy is conditioned by not only the processes of globalization and permanent growth of weight of the capital in provision of economic development but also by integration intentions of the national economic system that create the stable tendency as to the necessity of effective inclusion of economic processes of the national level in supranational politic-economic formations. The factors of especially economic level that are manifested as existent circle of sources of financing of the national economy, transformation and increase of the volume of investments in priority directions of economic activity have the direct influence on the change of national economy structure in the process of strengthening of integration processes.

The increase of the level of availability of sources of financing of structural shifts is manifested as activation of cooperation between Ukraine and international financial institutions.

In the modern conditions of integration processes Ukraine faced the urgent question of limitation of economic resources, overcoming of the socio-economic crisis, resumption of economic growth. Limitation of internal investment resources and also necessity of realization of the program of the structural renewal of economy cause the need of involvement of additional external sources of support for its development.

According to the experts, the main objective preconditions of structural integration of Ukrainian economy to European Union are the following ones: favorable geopolitical location of Ukraine that is between two global territorial-economic complexes - Euro-Asian and Baltic-Black Sea; the presence in Ukraine of such economic objects that are the component of international natural-economic structures (Carpathians, basin of the river Dnipro, Black Sea water area and so on); direct entrance of Ukrainian transport net (in its main part) in European transport system; possibility of the use of significant recreational-tourist potential of Ukraine; wide net of resource transit arteries. The entrance of Ukraine in EU opens to it the access to the series of instruments and means of stimulation of economic processes that were not available earlier.

\section{The prospects of cooperation between Ukraine and European structural funds}

Creation and functioning of the net of investment funds in European space is connected with the necessity of formation of stable investment flows that are directed on the structural transformation and general development of economy and also on the raise of social directionality of the state policy of member states and states-applicants for entrance to EU.

The main directions of financing of European funds are the creation of stable growing system of employment, financing of programs as to raise of environmental friendliness of production processes, overcoming of essential disproportion of the regional economic growth and also elimination of depressive regions. Financing of overcoming of the structural disproportions between regions is realized on the conditions of proportionality that provides covering of $75 \%$ of expenses, 
planned by the strategy, residue in $25 \%$ must be financed at the expanse of the own sources of the country-recipient [18-20].

In European economic space for the countries-applicants for entrance to EU the sources of activation of reformation of economic system and improvement of the structure of economy are the following funds: Instrument for the Structural Policies for Pre-accession (ISPA) and Special Action for the Pre-accession for Agriculture and Rural Development (SAPARD). ISPA fund is an instrument of financing and coordination of the structural policy within EU functioning, which priority directions are the sphere of optimization of the transport infrastructure and the raise of environmental friendliness of production processes [21]. SAPARD fund is responsible for the stimulation of structural shifts; the main direction of its activity is overcoming of disproportion of the regional development and guaranteeing of protection of the vulnerable sectors of economy. The one of priority directions of its activity is financing of technological renewal of agricultural production and improvement of the quality of its product and also the wide support of farmer economies. The investment course of SAPARD fund is directed on equation of development of the whole regional system according to European standards and approach of the intensity level of development of economies of regions to the most developed one and also the raise of social directionality of economic policy.

EU investment fund that acts within EU PHARE program was created for the support of administrative reforms, directed on adaptation of regulatory base and strategy of economic policy that is realized by administrative institutions of the countries-applicants according to general standards and strategy of EU economic development. The activity of this fund is also concentrated in creation of administrative units that realize EU PHARE program at the national level [22].

The main direction of activity of European Regional Development Fund (ERDF) is investment in the development of transport infrastructure. The priority of functioning of European Social Fund (ESF) is a financing of development of employment system and creation of the new workplaces for overcoming unemployment and also creation of organizations that are responsible for the improvement of staff qualification and retraining of unemployed people [23].

European Agriculture Guidance and Guarantee Fund (EAGGF) is a European fund that deals with an active investment support of agricultural sector as to improvement of conditions of functioning of farmer economies in unfavorable regional conditions, caused by geographical features of location, and also with support of the new farmer economies that just start their activity, stimulation of creation of agricultural enterprises by youth, improvement of structure, diversification of the new types of activity and technological renovation of agricultural enterprises, support of investments in the tourist sector, infrastructure investments. The aim of the fund is the formation of stable functioning and development of agricultural sector and optimal structure of economy at the regional level.

The activity of Financial Instrument for Fisheries Guidance (FIFG) is directed on the support of development of fishery by the way of technological renovation of production processes in this sector and also the favoring of development of marketing base of enterprises of this type of activity. The investments of fund are also directed on the raise of greening of the water resources that are used in production processes of the fishery and also for environmental protection of the sea territories [21, 23].

At the same time the feature of use of investment costs of EU structural funds are the prohibitions, created by EU commission including: the direct subsides, tax and fees immunity, free transfer of the land in use, preferential discount rates and the other methods of the direct stimulation [24]. The cause of these prohibitions is preservation of the principles of market economy and compliance with conditions of the free competition.

In the list of allowed forms of state stimulation are: the help that favors the economic development of the regions with extremely low level of life or with high level of unemployment, help that favors the realization of important project of the common European interest or overcoming of the serious disturbance of economy of the member state, help that favors the development of the certain types of economic activity or certain economic spheres, help that favors the cultural development and preservation of the cultural heritage and also other categories of help that can be outlined by the Rada's decision to the Commission's offer [25]. 
Within the structural state policy are also the directions of indirect state stimulation of economic development that have precedents of introduction in EU countries:

- regulation of the segments of export operation: support of export by creating export credit agencies of the state, private or mixed form of property (crediting, insurance, giving of state guarantees and also informational and organizational support of external trade operations [26];

- development of the state subjects of financial sector of investment directionality: development of national banks of development for financing of investment projects, compensation of the part of investments, co-financing and issuance of the guaranteeing obligations, diminution of interest rates, interbank crediting [27];

- state-private partnership in priority directions of economic activity according to the principles of corporative financing with $100 \%$ participation of private capital; grant financing within the state programs; projective financing with partial participation $70 \%$ and $30 \%, 80 \%$ and $20 \%$ : water supply, heat supply, processing of waste, electric power industry, transport infrastructure, sector of medical services, sector of tourist and cultural services [28];

- stimulation of development of SME: support of the small business by creation of agencies for supporting the small business of the state form of property (microcrediting, teaching of entrepreneurs, consulting and legal consultations, venture financing, credit programs, grants, businessombudsmen) [29];

- creation of the new economic structures at meso- and macro-level of economy: stimulation of creation of industrial parks as a partial state participation in investment projects, preferential regimes of interest rates on credits, preferential communal tariffs, preferential regime of tax on profit, preferential regimes of taxation for the natural persons-entrepreneurs, shortening of the volume of land tax, elimination of import duties, simplification of the order of registration and functioning of enterprise structures, state financing of development of infrastructure of industrial parks, state help in improvement of qualification and teaching of staff and new personnel [30].

6. The current state of directions of interaction between Ukraine and European investment bank

The one of the forms of investment interaction between Ukraine and EU is the partner relations with European investment bank. From 2004 Ukraine started to cooperate with EIB and to create the legal ground for attraction of financial resources for financing of the development of infrastructural and energetic sectors and also the projects of environmental and multi-sector purpose and other directions of structural policy. The frame agreement between Ukraine and EU, signed 16.06.2005, came into force 08.04.2006. Package of EIB services consists of: credits (the objects of investments can be the state authorities and also enterprise structures of the state and private forms of property), technical help (expert help of specialists in elaboration and realization of the projects in determined sector) and guaranteeing (provision of guarantees to banks, funds and leasing companies). The volumes of financing are up to $25 \mathrm{mln}$ euro for the middle projects, for the big ones more than $25 \mathrm{mln}$ euro, but not more than $50 \%$ of the general value of the project or on the principles of common financing with EBRD in the case of increase of investment costs.

The profile directions of EIB activity in Ukraine are the raise of environmental friendliness of production processes for protecting the environment, improvement of technologies of waste processing, stimulation of development and renewal of energetic and transport infrastructure, telecommunication, development of energy efficiency of the national economy, programs of crediting of the private business [31].

The general volume of investment projects of EIB in Ukraine is more than 1 billion euro. To the main projects that are realized within the cooperation between Ukraine and EIB must be assigned the following financial agreements:

- in the sector of transport infrastructure: "European highways" - repair of the highway KyivChop of 2008 in volume $200 \mathrm{mln}$ euro and "European highways II" - improvement of highways around Kyiv of 2012 in volume 450 mln euro, development of the rail connection "Building of Bexidsky tunnel" of 2014 in volume $55 \mathrm{mln}$ euro, improvement of the air connection "Modernization and improvement of aeronautical system" of 2013 in volume $41 \mathrm{mln}$ euro. The main aim of these projects is an improvement of quality and development of transport services; 
- within the support of development of the private sector of economy: EIBrealizes crediting through the subjects of financial infrastructure of Ukraine with the volume of resource financial base $660 \mathrm{mln}$ euro, the project "Building of Vinnitsa battery farm" of 2013, "investment program of Astarta-Kyiv company" for 2012-2014;

- multi-sector greening of production processes and protection of environment: the project "Fund of the green growth II" of 2013 in volume 2,5 mln euro, "Environmental project of the private fund «DASOS TIMBERLAND» in volume $3 \mathrm{mln}$ euro;

- in educational sector the projects of cooperation in pre-school education, technical and other universities of 2013 with prognosticated volume $200 \mathrm{mln}$ euro;

- agreement as to modernization of the arterial gas pipeline "Urengoy-Pomary-Uzhgorod" (the sum of loan - $150 \mathrm{mln}$ euro) and the project "Main capital for the small and middle enterprises and companies with the middle level of capitalization" (the sum of loan - $400 \mathrm{mln}$ euro);

- since April of 2015 in Ukraine is realized the project "Exclusive credit program for Ukraine" that provides financing of renewal of municipal infrastructure of the territories, suffered from the military action and are under the control of Ukrainian side (the sum of loan - $200 \mathrm{mln}$ euro);

- in 2016 the Ministry of finances of Ukraine involved EIB credit in volume $400 \mathrm{mln}$ euro for the credit support of the real sector of Ukrainian economy and development of the small and middle business [32-34].

The investment possibilities of EIB allow widen the cooperation in the direction of development and optimization of functioning of energetic infrastructure. At current time the credit portfolio of EIB in Ukraine is not sufficiently realized in direction of cooperation in agricultural sphere taking into account its importance for provision of the social sphere needs, vulnerability as to growth of competitive advantages of foreign producers and insufficient technological development.

The one of the main priorities in direction of activation of cooperation with EIB is optimization of the monitoring of use of investment costs by the way of rise of effectiveness of activity of correspondent state structures that must not only coordinate the realization of projects but also create the scientific ground of their introduction within the realization of economical development strategy.

\section{The features of interaction between Ukraine and EBRD}

The next international financial institution that Ukraine cooperates with is EBRD. Ukraine gained the status of member state of EBRD according to the Order of president of Ukraine "On the membership of Ukraine in European bank for reconstruction and development" of 4 of July, 1992 № 379/92 and correspondent agreements with EBRD. At this stage EBRD is one of the main investors that has a wide portfolio of services in Ukraine, which structure is a complex one and has a wide spectrum of investment directions.

As of 1 of January, 2014 EBRD portfolio in Ukraine consists of 337 projects with the general volume of financing more than 8,7 billion euro.

For the period of cooperation with EBRD (1993-2014) in the state sector of economy on the projects, which credit costs were involved by the state or on the state securities, were made agreements for the general sum 674,94 mln US dollars and 487,35 mln euro (within 23 projects).

The branch structure of credit portfolio of EBRD projects in the state sector of economy is formed in such a way that $50 \%$ of the whole credit portfolio is directed on financing of projects of transport infrastructure development, $39 \%$ - on the support of projects in energetic sphere, the other in financial one ( $8 \%$ ), connection $(2 \%)$ and municipalities development $(1 \%)[32,33]$.

The volumes of EBRD investment resources directly correlate with transparency and effectiveness of introduction of reforms, directed on preservation of conditions of the market economy, development of free competition and correspondence to European economic standards. The increase of volumes of EBRD investment costs for Ukraine depends on effectiveness of introduction of anti-corruption arrangements, rise of effectiveness of judicial system of Ukraine, diminution of politization of tariff-creation, reformation of NSC "Oil-gas" and so on. 


\section{Conclusions}

As a result of the studies:

1. It was established, that cooperation with the EU structural funds has a great potential for Ukraine, taking into account the volumes of resources that can be directed on regulation of the national economy and also qualification of the expert assessment for making the rational economic decisions. The strengthening of activity of European integration vector has a great importance for the full inclusion of Ukraine in the system of international division of labor. The effectiveness of the prospects of cooperation between Ukraine and EU structural funds depends on the level of adaptation of Ukrainian economy to the system of European standards.

2. The current state and prospects of interaction between Ukraine and EIB count the significant number of projects in the different sectors of economy. Concentration of flows of EIB investment costs must take place taking into account the real needs of the national economy development. The prior tasks of improvement of the use of external credit sources such as investment projects of EIB in Ukraine must be actualized to the real current economic situation and concentrated in the direction of stimulation of the development of the sector of infrastructure support of economic processes of reformation and improvement of energetic and agricultural sectors and also the increase of investment of scientific activity as a source of economy renewal. In this context the strict realization of requirements of international agreements and conditions of EU convergence as priority direction of development of external economic connections of Ukraine gain the great importance.

3. Optimization of interaction between Ukraine and EBRD directly correlates with elaboration of determined and grounded strategy of the national economic development and structural rebuilding of economy, establishment of the distinct regulation of the use of financial credit capital and also improvement of the system of state control over its use. At the same time the problem of increase of external credit loans that under condition of ineffective introduction of credit projects can result to uncontrolled increase of external debt of the national economy still be topical. That is why the use of external credit resources must be grounded not only within the programs of national economic growth but also must take into account the experience of European countries in cooperation with international and regional financial institutions.

\section{References}

[1] Pentland, C., Hooghe, L. (1997). Cohesion Policy and European Integration: Building Multi-Level Governance. International Journal, 52 (2), 382. doi:10.2307/40203211

[2] Hay \& Menon: European Politics. Oxford University Press. Available at: http://global.oup.com/ uk/orc/politics/comparative/hay_menon

[3] Warleigh-Lack, A. (2008). European Union: the basics. Routledge, 192.

[4] Rodriguez-Pose, A., Fratesi, U. (2004). Between Development and Social Policies: The Impact of European Structural Funds in Objective 1 Regions. Regional Studies, 38 (1), 97-113. doi:10.1080/ 00343400310001632226

[5] Bachtler, J., McMaster, I. (2008). EU Cohesion policy and the role of the regions: investigating the influence of Structural Funds in the new member states. Environment and Planning C: Government and Policy, 26 (2), 398-427. doi:10.1068/c0662

[6] Ederveen, S., Groot, H. L. F., Nahuis, R. (2006). Fertile Soil for Structural Funds?A Panel Data Analysis of the Conditional Effectiveness of European Cohesion Policy. Kyklos, 59 (1), 17-42. doi:10.1111/ j.1467-6435.2006.00318.x

[7] Puigcerver-Peñalver, M. C. (2007). The impact of structural funds policy on European regions' growth. A theoretical and empirical approach. The European Journal of Comparative Economics, 4 (2), 179.

[8] Streimikiene, D., Klevas, V., Bubeliene, J. (2007). Use of EU structural funds for sustainable energy development in new EU member states. Renewable and Sustainable Energy Reviews, 11 (6), 1167-1187. doi:10.1016/j.rser.2005.07.006

[9] Malan, J. (2006). Evaluation Capacity in the New EU Member States. In CSES, European Evaluation Society. United Kingdom, 9.

[10] PINDER, D. A. (1986). Small Firms, Regional Development and The European Investment Bank. JCMS: J Common Market Studies, 24 (3), 171-186. doi:10.1111/j.1468-5965.1986.tb00092.x 
[11] Robinson, N. (2009). The European Investment Bank: the EU's neglected institution. JCMS: Journal of Common Market Studies, 47 (3), 651-673. doi:10.1111/j.1468-5965.2009.01818.x

[12] Schure, P., Wagenvoort, R. (1999). Economies of scale and efficiency in European banking: new evidence. European Investment Bank, 52.

[13] Honohan, P. (1995). The public policy role of the European Investment Bank within the EU. JCMS: Journal of Common Market Studies, 33 (3), 315-330. doi:10.1111/j.1468-5965.1995.tb00537.x

[14] Kastratović, R. (2015). European bank for reconstruction and development. Bankarstvo, 44 (2), 74-93. doi:10.5937/bankarstvo1502074k

[15] Strand, J. (2003). Power relations in an embedded institution: The European bank for reconstruction and development. Journal of European Integration, 25 (2), 115-129. doi:10.1080/07036330305625

[16] Bocharov, S. (2012). European integration: Poland's experience and Ukraine's prospects. Bulletin of Lviv University. Series: International relations, 31, 37-42.

[17] Shynkaruk, L., Bevz, I., Baranovska, I. (2015). Structural transformations in the economy of Ukraine: dynamics, contradictions and impact on the economic development. Scientific report, Institute of Economics and Forecasting of the NAS of Ukraine, Kyiv.

[18] P'iatnyts'kyj, V. (2000). Yevropejs'kyj Soiuz: osnovy polityky, instytutsijnoho ustroiu ta prava. Berlin: Tovarystvo Karla Dujsberha.

[19] Rybynska, A., Tokaj-Kshevska, A. (2003). Otchet o sostoianyy sektora malykh y srednykh predpryiatyj v Pol'she v 2001-2002 hh. Varshava: Pol'skoe ahentstvo razvytyia predprynymatel'stva, 440.

[20] Nykytiuk, T. L. (2008). Strukturni fondy Yevrosoiuzu: mekhanizm finansuvannia rehional'noho rozvytku. Zbirnyk naukovykh prats' LDTU. Ekonomichni nauky, 5 (20), 56-64.

[21] Bila, S. O. (2001). Strukturna polityka v systemi derzhavnoho rehuliuvannia transformatsijnoi ekonomiky. Kiyv: UADU, 506.

[22] Bila, S. (2000). Intehratsijni aspekty strukturnoi polityky Ukrainy (spivrobitnytstvo z YeS). Komandor, 2-3, 26-30.

[23] Economic Development of Latvia (1999). Ministry of Economy Republic of Latvia, Riga.

[24] Piaseck, B., Rogut, A., Stawasz, E., Jonson, S., Smallbone, D. (1998). Warunki prowadzenia działalności gospodarczej przez MSP w Polsce I krajach Unii Europejskiej, Warszawa.

[25] Consolidated versions of the Treaty on the European Union and the Treaty on the Functioning of the European Union. Official Journal of the European Union. Available at: www.minjust.gov.ua/file/23491.PDF

[26] Dyrektyva Rady YeS 98/29/YeS (1998).

[27] Commission Regulation (EU) No 651/2014 (2014). Declaring certain categories of aid compatible with the internal market in application of Articles 107 and 108 of Treaty. Available at: https://www.gov.uk/ government/uploads/system/uploads/attachment_data/file/417293/GBER_2014.pdf

[28] Dyrektyva Rady YeS 2004/49/YeS (2004). Available at: http://zakon5.rada.gov.ua/laws/ show/994_953

[29] The Small Business Act for Europe. Available at: http://ec.europa.eu/growth/smes/business-friendly-environment/small-business-act_en

[30] Traktat ustanavlyvaiuschyj Evropejskyj Soiuz. Chast' III, Razdel 2 pravo predprynymatel'stva y Razdel 3 Usluhy. Available at: https://wwwl.ukie.gov.pl/uk.nsf/B-EC-T

[31] Viblyj, I., Horbova, Kh. (2014). Perspektyvy investytsijnoho spivrobitnytstva Ukrainy z Yevropejs'kym Soiuzom. Naukovyj visnyk NLTU Ukariny, 21 (1), 197-203.

[32] Ukrains'ka pryzma: spivpratsia Ukrainy z mizhnarodnymy orhanizatsiiamy (2014). Available at: http://www.fes.kiev.ua/new/wb/media/publikationen/prizma_ukr_int_2014.pdf

[33] Ministry of Finance of Ukraine. Available at: http://www.minfin.gov.ua

[34] Executive power bodies of Ukraine. Available at: http://www.kmu.gov.ua 